\title{
Public health concerns and implications of medical tourism in Penang
}

\author{
CHOW Sze Loon ${ }^{a}$
}

a DrPH; MPH; MB BS., District Epidemiology Officer, Public Health Medicine Specialist, Penang, Malaysia.

\begin{abstract}
Medical tourism is a growing industry in Malaysia, but it is not without its own public health implications. Despite the growing importance of medical travel, little is known of its impact, especially in relation to the public health concerns of the receiving countries. This paper aims to explore the various public health concerns and issues faced by Penang, a popular destination for medical tourism in South East Asia (S.E.A). It also highlights the changes on socio demographics in certain residential areas which cater to medical tourists, the risk of importing undetected infectious diseases like TB through medical tourists, and the strain on the public health system due to limited resources left for local patients. This paper also highlights the future direction in which the medical tourism should be regulated in order to mitigate the spread of infectious diseases (e.g. TB) across borders.
\end{abstract}

Key words: Medical tourism, public health concerns, infectious disease, Tuberculosis, Malaysia

\section{Penang'da sağlık turizminin halk sağlığı etkileri ve sonuçları}

Öz

Sağlık turizmi Malezya'da büyüyen bir endüstridir, ancak kendi halk sağlığı etkileri olmadan değil. Tıbbi seyahatin artan önemine rağmen, özellikle turist alan ülkelerdeki halk sağlığını ilgilendiren etkileri az bilinir. Bu çalışma, Güneydoğu Asya'da sağlık turizmi için popüler bir yer olan Penang'ın karşılaştığı çeşitli halk sağlığı etki ve sorunlarını araştırmayı amaçlamaktadır.

Correspondence to: CHOW Sze Loon, District Epidemiology Officer, Public Health Medicine Specialist, Southwest District Health Office, 2761, Jalan Air Putih, Titi Teras, 11000 Balik Pulau, Penang, Malaysia. E-mail: $\underline{\text { drslchow@gmail.com }}$

Copyright holder Turkish Journal of Public Health

This work is licensed under a Creative Commons Attribution-NonCommercial 4.0 International License. (कc) EY-NC This is an open Access article which can be used if cited properly. 
Ayrıca, bu çalışma sağlık turistlerine hitap eden bazı yerleşim bölgelerindeki sosyo demografik değişimleri, tüberküloz gibi tanı konmamış bulaşıcı hastalıkların sağlık turistleri kaynaklı ülkeye giriși ve yerel hastalara bırakılan sınırlı kaynaklardan dolayı halk sağlığı sistemi üzerindeki baskıya işaret etmektedir. Bu makale ek olarak TB gibi bulaşıcı hastalıkların sınır ötesi yayılımını azaltmak için gelecekte sağlık turizminin düzenlenmesi gerekliliğini de vurgulamaktadir.

Anahtar kelimeler: Sağlık turizmi, halk sağlığı etkileri, enfeksiyon hastalıkları, tüberküloz, Malezya

\section{Introduction}

Healthcare travellers to Malaysia are classified under four categories: i) Medical tourists seeking medical treatment, ii) Holidaymakers falling sick during travels, iii) Expatriates and their families residing in Malaysia, and iv) Investors in Malaysia My Second Home (MM2H) programme.

Better quality healthcare, shorter waiting lists for treatment, legal or cultural restrictions at home countries, privacy reasons, opportunity to recover away from home, and incentives offered by employers or insurers, are the common motivators for individuals to travel abroad for medical treatment. 1,2

Majority of healthcare travellers in Malaysia were from Indonesia (62\%) due to the close proximity and the cheap airfares offered by budget airlines. Indonesians seeking treatment abroad for infectious diseases is not uncommon, though such services are not promoted in medical tourism. Half of the multidrug-resistant TB (MDR-TB) cases in Singapore were contributed by medical tourists from Indonesia. ${ }^{3}$ This number should concern policy makers in Penang, as seeking medical treatment in Penang is convenient, and without communication nor cultural barriers for the Indonesians.

\section{Risk of importing infectious diseases during air travel}

Tuberculosis (TB) incidence in Indonesia is the second highest, after India. ${ }^{4}$ It is common for Indonesian patients seeking a second opinion in Penang without disclosing their initial diagnosis made in their home country as an infectious disease. Therefore, such practice is not captured in the database of Malaysia Healthcare Travel Council (MHTC).

Air travel from Indonesia to Penang is less than 8 hours; hence hypothetically, the risk of TB transmission on board is low. ${ }^{5}$ However, the number of potentially active TB cases in the same aircraft may suggest otherwise.

\section{Unexpected exposure among healthcare workers}

Individuals involved in handling foreign travellers from the airport until their arrival at the hospitals are exposed to potentially infectious TB. Depending on their presentations, they are being transferred to outpatient, ward or even emergency departments. Therefore, this could be an emerging occupational hazard which has yet to be addressed. In Singapore, extensively resistant TB was diagnosed in 2010 in an Indonesia healthcare traveller and strict infection control measures were observed for months to mitigate the risk of TB transmission to the healthcare workers. ${ }^{6}$

\section{Mushrooming of homestays for healthcare tourists}

Following the influx of foreign patients coming to Penang, many residential properties have been converted into shortterm homestays. Lack of enforcement on this aspect encourages more apartments or landed properties to join in providing shortterm homestays for the medical tourists. These medical tourists could be harbouring some infections during treatment, which may spread to the local community during the homestay. Toxic biological waste products following chemotherapy requires special handling, which is unavailable in homestays, making it a potential 
environmental hazard to the residential area.

\section{Challenges in ensuring continuum of care}

TB patients are advised to continue TB treatment in their home country, once the diagnosis is made. However, many still prefer to continue TB follow-ups in Penang. Travelling across borders for treatment may be interrupted, in the event of unforeseen circumstances such as inability to purchase air tickets to the destination.

Follow-up as part of the continuum of care in the home country does not take place usually ${ }^{7}$, giving rise to serious implications for the individuals and also the local healthcare system. Complications arising from malpractice abroad and local doctors being reluctant to receive the patients in view of medicolegal implications, have been reported. ${ }^{8}$

\section{Impact on the public healthcare}

Maldistribution of healthcare resources catering for the needs of foreign patients may lead to a rise in the cost of some surgical procedures and health insurance premiums, making them less affordable for the local patients. ${ }^{9}$

Penang being the destination of choice for medical tourism has spilled over into the public hospital following the referral of healthcare travellers to public hospitals due to limited resources in the private setting. It has created a greater strain on the already overworked government healthcare providers.

Provision of healthcare services as a commodity to foreign patients might worsen an internal brain drain driving healthcare experts from the public service to the private sector, thereby reducing access to care for the local patients. ${ }^{10}$

\section{Recommendations}

Outlining the specific criteria on fitness for air travel in keeping with the health safety of the passengers is crucial to minimize the risk of infectious disease transmission. Exit screening at point of departure may create public reassurance that public health measures are being taken to mitigate the spread of infectious diseases.

More campaigns against travelling with suspected infectious diseases must be carried out in home countries. Any plan to travel abroad to seek a second opinion, or further treatment should only be considered if the initial infection is being controlled and the patient is deemed non-infectious. A letter to certify fitness and safety to fly, issued by the treating physician would help in the subsequent air travel.

Physicians must provide a clear, written anti-TB regimen to ensure the continuum of care is achieved upon returning home. Currently, foreigners diagnosed with TB would be sent back to their countries after receiving the initial TB treatment in healthcare facilities. The integrated biometric system has been introduced and relevant documents are being submitted to the Airport Health Office and Immigration Department to ascertain the travellers' departure for home.

There is no regulation on the code of conduct for the medical brokerage industry. Without medical background, methods used by brokers to gauge and evaluate the quality of healthcare are questionable. Hence, regulating the medical tourist brokers should be top priority. Basic public health issues pertaining to medical tourism must be delivered to new medical brokers prior to registration for license. With such implementation, the medical brokers are trained and could play a vital role in advising patients and reducing the influx of infectious diseases carriers to the destination country.

The homestay business, catering for the medical tourists, has changed the sociodemographic makeup of the existing residential communities. Unless the local council enforces the existing act, the phenomenon is not going to change for the better for the local community. The main concerns for the residents are the potential infectious patients living together in the community, and the hygiene, following the high turnover of the medical tourists in the homestays. 
Medical tourism could exacerbate the already-endemic public to private brain drain in the region. Introducing standardised fees for doctors, regardless of local or foreign patients and regulated dual practice of specialists in public and private services are the current recommendations to mitigate the internal brain drain.

\section{Conclusion}

Medical tourism is a growing industry in Malaysia, but it is not without some public health implications.

In the future, medical tourism may be regulated to prevent the import of infectious diseases to the host country. However, this requires the stakeholders of medical tourism to buy in the need to identify and address the infectious disease burden at the respective countries, with the aim of improving the domestic healthcare system that could serve a bigger local population.

Globalisation and the rapid travel of patients have introduced some new challenges in the public health implementation and surveillance. Therefore, the next step for epidemiological data monitoring and surveillance system is to expand beyond the country's borders by optimising the use of information technology (IT) or even artificial intelligence (AI). The sharing of such databases or repository at regional or international level is necessary in helping to identify and prevent cross border infectious diseases.

\section{References:}

1. Samir N, Karim S. An insight: medical tourism, local and international perspective. Oman Med J 2011; 26(4):215.

2. Turner LG. Quality in health care and globalization of health services: accreditation and regulatory oversight of medical tourism companies. Int J Qual Health Care 2011;23(1):1-7.

3. Chee CBE, KhinMar KW, Cutter J, Wang YT. The imminent threat of multidrug- resistant tuberculosis in Singapore. Singapore Med J 2012; 53(4):238.

4. WHO. Estimates of TB and MDR-TB burden are produced by WHO in consultation with countries. WHO, 2016.

5. WHO. Tuberculosis and air travel: guidelines for prevention and control 3rd ed, Geneva: World Health Organisation, 2013

6. Phua CK, Chee CB, Chua AP, Gan SH, Ahmed AD, Wang YT. Managing a case of extensively drug-resistant (XDR) pulmonary tuberculosis in Singapore. Ann Acad Med Singapore 2011;40(3):132.

7. Helble M. The movement of patients across borders: challenges and opportunities for public health. Bull World Health Organ 2011;89(1):68-72.

8. Forgione DA, Smith PC. Medical tourism and its impact on the US health care system. J Health Care Finance 2007; 34:27-35. PMID:18972983.

9. Cohen E. Medical tourism in Thailand. AU-GSB e-journal 2008; 1:24-37. Available at http://www.assumptionjournal.au.edu/ index.php/AU-GSB/article/view/381 Accessed December 14, 2018.

10. Chinai R, Goswami R. Medical visas mark growth of Indian medical tourism. Bull World Health Organ 2007; 85:164-5. 